\title{
SOCIAL MEDIA: THE MEETING BEFORE THE MEETING
}

\author{
JARMICHAEL R. HARRIS*, KRISTINE DE JESUS \\ *HARRISJA15@ECU.EDU; CENTER FOR COUNSELING AND STUDENT DEVELOPMENT, 137 UMSTEAD BUILDING \\ MAILSTOP 411 EAST CAROLINA UNIVERSITY GREENVILLE, NC 27858
}

To cite this article: Harris, J. R. \& De Jesus, K. (2018). Social Media: The Meeting Before the Meeting. Journal of Recovery Science, $1(2)$, c12. https://doi.org/10.31886/jors.12.2018.32

To link to this article: https://doi.org/10.31886/jors.12.2018.32

\section{ABSTRACT}

Now, more than ever, many students' first contact with your program very well could be from your social media presence. This roundtable will explore helpful communicating tips and tools to bridge the intergenerational gap between staff and students that will help participants engage students and introduce their program to a broader audience.

\section{THE NEUROSCIENCE OF HIGH-RISK BEHAVIOR: IMPLICATIONS FOR PREVENTION \& TREATMENT IN YOUTH CRYSTAL COLLIER*}

*CRYSTAL@DRCRYSTALCOLLIER.COM; THE HOPE \& HEALING CENTER

To cite this article: Collier, C. (2018). The Neuroscience of High-Risk Behavior: Implications for

Prevention \& Treatment in Youth. Journal of Recovery Science, 1(2), c12. https://doi.org/10.31886/jors.12.2018.33

To link to this article: https://doi.org/10.31886/jors.12.2018.33

\section{ABSTRACT}

The average age of first use of alcohol for teen boys is 11 and 13 for teen girls. The average age of first exposure to pornography is 9 . More teens are suffering from depression than any other time in our history due to too much screen time. Cyberbullying peaks in the 6th grade. What is happening in our culture and to our children's neurodevelopment as a result of it? Engaging in high-risk behavior as a teen increases the chance of struggling with addiction as an adult by up to $90 \%$ due neurodevelopmental exposure and priming of the mesolimbic reward system. The Neuroscience of High-Risk Behavior elucidates how substances and other risky behavior, such as technology overuse, affect healthy neurodevelopment and how these effects impair adult functioning as well as implications for prevention and treatment. Practical, every-day parenting solutions and clinical techniques will be discussed.

All authors approve this manuscript and the original submission. The authors report no conflicts of interest. This work is licensed under the CC-BY license. 